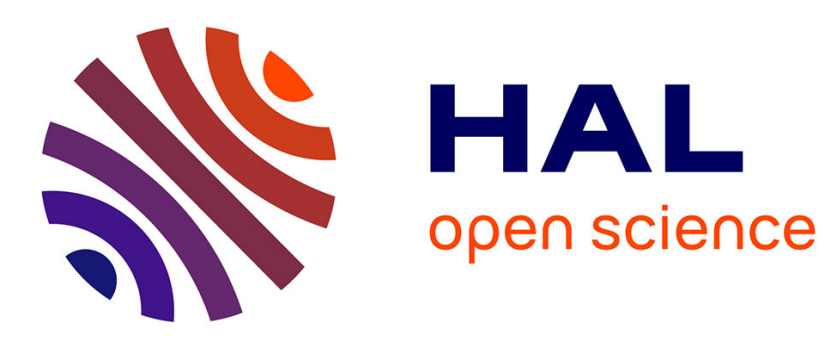

\title{
Noncompaction on scleroderma
}

\author{
Sinda Zarrouk-Mahjoub, Josef Finsterer
}

\section{To cite this version:}

Sinda Zarrouk-Mahjoub, Josef Finsterer. Noncompaction on scleroderma. Türk kardiyoloji derneği arşivi, 2016, 44 (2), pp.189-191. 10.5543/tkda.2016.34280 . pasteur-01447762

\section{HAL Id: pasteur-01447762 https://hal-riip.archives-ouvertes.fr/pasteur-01447762}

Submitted on 27 Jan 2017

HAL is a multi-disciplinary open access archive for the deposit and dissemination of scientific research documents, whether they are published or not. The documents may come from teaching and research institutions in France or abroad, or from public or private research centers.
L'archive ouverte pluridisciplinaire $\mathbf{H A L}$, est destinée au dépôt et à la diffusion de documents scientifiques de niveau recherche, publiés ou non, émanant des établissements d'enseignement et de recherche français ou étrangers, des laboratoires publics ou privés. 
Red cell distribution width and contrast-induced nephropathy in patients who underwent primary percutaneous coronary intervention

\section{Dear Editor,}

The recent report by Akkoyun et al. on red cell distribution width (RDW) and contrast-induced nephropathy $(\mathrm{CIN})$ in patients who underwent primary percutaneous coronary intervention (PCI) is very interesting. ${ }^{[1]}$ Akkoyun et al. found that, "Compared to the CINnegative group, CIN-positive patients had increased RDW values." "[1] The authors concluded that RDW was an independent predictor of CIN in patients who underwent PCI. ${ }^{[1]}$ This conclusion was also reached in a recent study by Kurtul et al. ${ }^{[2]}$ Indeed, while RDW values may be useful, several concerns exist regarding the measurement of RDW. First, RDW values obtained from various kinds of automated hematology analyzers are usually different. ${ }^{[3]}$ For example, Bollinger et al. found poor correlation between RDW values obtained from an automated hematology analyzer, a Technicon $\mathrm{H} 1$, and instrumentation reference. ${ }^{[4]}$ In addition, many pathophysiological factors such as anemia ${ }^{[5]}$ and smoking ${ }^{[6]}$ can cause deviations in RDW results.

\section{Somsri Wiwanitkit, M.D., Viroj Wiwanitkit, M.D.\#}

Wiwanitkit House, Bangkhae, Bangkok, Thailand "Hainan Medical University, China

e-mail: somsriwiwan@hotmail.com

\section{doi: 10.5543/tkda.2016.34280}

Conflict-of-interest issues regarding the authorship or article: None declared

References

1. Akkoyun DÇ, Akyüz A, Kurt Ö, Bilir B, Alpsoy Ş, Güler N. Relationship between red cell distribution width and contrastinduced nephropathy in patients who underwent primary percutaneous coronary intervention. Turk Kardiyol Dern Ars 2015;43:613-20. CrossRef

2. Kurtul A, Yarlioglues M, Murat SN, Demircelik MB, Acikgoz SK, Ergun G, et al. Red cell distribution width predicts contrast-induced nephropathy in patients undergoing percutaneous coronary intervention for acute coronary syndrome. Angiology 2015;66:433-40. CrossRef

3. Savage RA. Calibration bias and imprecision for automated hematology analyzers. An evaluation of significance of shortterm bias resulting from calibration of an analyzer with S Cal. Am J Clin Pathol 1985;84:186-90. CrossRef

4. Bollinger PB, Drewinko B, Brailas CD, Smeeton NA, Trujillo JM. The technicon $\mathrm{H}^{*} 1$-an automated hematology analyzer for today and tomorrow. Complete blood count parameters. Am J Clin Pathol 1987;87:71-8. CrossRef

5. Das Gupta A, Hegde C, Mistri R. Red cell distribution width as a measure of severity of iron deficiency in iron deficiency anaemia. Indian J Med Res 1994;100:177-83.

6. Subhashree AR, Shanthi B, Parameaswari PJ. The red cell distribution width as a sensitive biomarker for assessing the pulmonary function in automobile welders- a cross sectional study. J Clin Diagn Res 2013;7:89-92. CrossRef

\section{Authors' reply}

\section{Dear Editor,}

We would like to thank the authors for their comments and criticism of our original investigation, entitled "Red cell distribution width and contrast-induced nephropathy in patients who underwent primary percutaneous coronary intervention." "[1]

We concluded that the group positive for contrast-induced nephropathy (CIN) had higher red cell distribu- tion width (RDW) than the CIN-negative group. As mentioned, this result was supported by the findings of Kurtul et al. ${ }^{[2]}$ Indeed, measurement of RDW may be affected by factors including anemia and smoking, and may differentiate when obtained using an automated hematology analyzer.

Our manuscript would have been improved by the citing of these factors as limitations.

Dursun Çayan Akkoyun, M.D., Aydın Akyüz, M.D., Ömer Kurt, M.D.," Bülent Bilir, M.D., * Şeref Alpsoy, M.D., Niyazi Güler, M.D. 
Department of Cardiology, Namik Kemal University Faculty of Medicine, Tekirdağ, Turkey

\#Department of Urology, Namik Kemal University Faculty of Medicine, Tekirdağ, Turkey

*Department of Internal Medicine, Namik Kemal University Faculty of Medicine, Tekirdağ, Turkey

e-mail: cayanakkoyun@gmail.com

Conflict-of-interest issues regarding the authorship or article: None declared

\section{References}

1. Akkoyun DÇ, Akyüz A, Kurt Ö, Bilir B, Alpsoy Ş, Güler N. Relationship between red cell distribution width and contrastinduced nephropathy in patients who underwent primary percutaneous coronary intervention. Turk Kardiyol Dern Ars 2015;43:613-20. CrossRef

2. Kurtul A, Yarlioglues M, Murat SN, Demircelik MB, Acikgoz SK, Ergun G, et al. Red cell distribution width predicts contrast-induced nephropathy in patients undergoing percutaneous coronary intervention for acute coronary syndrome. Angiology 2015;66:433-40. CrossRef

\section{Noncompaction and scleroderma}

\section{Dear Editor,}

We read with interest the case report by Kalayci et al. about a 40-year-old female with diffuse cutaneous sclerosis (scleroderma) in whom left ventricular hypertrabeculation/noncompaction (LVHT) was detected upon echocardiographic investigation because of cardiomegaly. ${ }^{[1]}$ We have the following comments and concerns.

LVHT is frequently associated with genetic disorders, particularly chromosomal defects, primary cardiomyopathies, and neuromuscular disorders. ${ }^{[2,3]}$ Did the authors consider a double trouble in the presented patient? Genetic disorders most frequently associated with LVHT are mitochondrial disorders. ${ }^{[2]}$ Were there any indications for muscle disease, such as muscle cramps, easy fatigability, exercise intolerance, myotonia, myalgia, wasting, fasciculations, or weakness? Was creatine kinase elevated? Was needle electromyography myopathic? Were there any indications for multisystem disease? Were organs or tissues other than the skin or heart affected? Were there indications for pancytopenia or eosinophilia? Were there other congenital defects or dysmorphism? Was there consanguinity of the parents?

As LVHT occurs familiarly, ${ }_{,}^{[4]}$ it is essential to know whether LVHT is present in other family members. Were cardiac symptoms or signs reported in any firstdegree relative? Were first-degree relatives systematically screened for LVHT? As LVHT may remain asymptomatic for years in a number of patients, there is a need to actively search for it.

As the right ventricle is physiologically hypertra- beculated, and no cut-off is available to differentiate between normal and abnormal hypertrabeculation of the right ventricle, noncompaction of the right ventricle or biventricular noncompaction should not be diagnosed. So far, noncompaction is an abnormality exclusively of the left ventricle.

Cutaneous sclerosis in association with LVHT has been described in a 75 -year-old male. ${ }^{[5]}$ In addition to LVHT and systemic sclerosis, this patient presented with anemia, leukopenia, thrombocytopenia, cataract, ptosis, myopathy, and polyneuropathy. ${ }^{[5]}$ He died 5 months after diagnosis. Were any of these abnormalities observed in the patient currently presented?

Scleroderma may be associated with malignancy. Was the patient investigated for occult neoplasia? Was the history positive for previous malignancy? Were there clinical indications for neoplasm, such as nightly sweating, weight loss, anemia, fatigue, or adenoma?

Systemic sclerosis is frequently associated with myocarditis. Did the presented patient undergo cardiac MRI with contrast medium to aid in the search for myocarditis, or was an endomyocardial biopsy performed? Was late gadolinium enhancement, indicating myocardial fibrosis, found on cardiac MRI? Did the patient receive any type of treatment? Did treatment of systemic sclerosis also affect the cardiac abnormalities?

Overall, this interesting case should be supplemented with information regarding genetic background, investigation of other family members for LVHT, and findings of cardiac MRI or endomyocardial biopsy. LVHT may be causally unrelated to systemic sclerosis and may be due to a second subclinical or mildly manifesting second genetic trouble. 
As a result, noncompaction may be causally unrelated to cutaneous sclerosis, and this coexistence may be due to a second genetic trouble.

\section{Sinda Zarrouk-Mahjoub, PhD., Josef Finsterer, M.D."}

Genomics Platform, Pasteur Institute of Tunis, Tunisia

"Krankenanstalt Rudolfstiftung, Vienna, Austria

e-mail: fifigs1@yahoo.de

doi: $10.5543 /$ tkda.2016.35040
Conflict-of-interest issues regarding the authorship or article: None declared

\section{References}

1. Kalaycı B, Kalaycı S, Karabă̆ T, Aydın M. Biventricular noncompaction cardiomyopathy with severe systolic and diastolic dysfunction in a systemic sclerosis patient. Turk Kardiyol Dern Ars 2015;43:720-3. CrossRef

2. Finsterer J. Cardiogenetics, neurogenetics, and pathogenetics of left ventricular hypertrabeculation/noncompaction. Pediatr Cardiol 2009;30:659-81. CrossRef

\section{Authors' reply}

\section{Dear Editor,}

We would like to thank the authors for their interest and valuable contributions to our case. ${ }^{[1]}$ We acknowledge the coexistence of neuromuscular disorders and left ventricular noncompaction cardiomyopathy. ${ }^{[2]}$ However, no manifestation of neuromuscular disorders including myotonia, myalgia, wasting, fasciculations, muscle cramps, or polyneuropathy were present in the patient. In addition, her creatine kinase level was normal. The patient had weakness due to left ventricular systolic dysfunction. Because of this, needle electromyography was not considered. Though there was no familial history of sudden cardiac death or heart failure, echocardiographic screening of family members was recommended.

While coexistence of left ventricular noncompaction and cutaneous sclerosis has been documented, ${ }^{[2]}$ our patient had left ventricular noncompaction and myopathy, polyneuropathy, pancytopenia, and eosinophilia. No severe ventricular dysfunction or right ventricular involvement was observed. Complete blood count parameters were normal, aside from anemia.

While we acknowledge that there is no cut-off to differentiate normal and abnormal hypertrabeculation of the right ventricle, right atrial and ventricular enlargement, hypertrabeculation of the right ventricle, moderate tricuspid regurgitation, pulmonary hypertension, and decreased tricuspid annular plane systolic excursion (TAPSE: $10 \mathrm{~mm}$ ) were observed. In addition, diffuse cutaneous systemic sclerosis (SSc) had been newly diagnosed. It was decided that these manifestations could be attributed to noncompaction cardio- myopathy. It is recommended that genetic analysis be performed on the patient and her family members.

Endocardial and myocardial inflammation may be more relevant in cases of systemic sclerosis. ${ }^{[3]}$ In our patient, echocardiographic examination indicated left ventricular noncompaction, and likely myocardial inflammation was present. However, she had not undergone any advanced imaging or invasive procedures such as cardiac MRI or endomyocardial biopsy.

As a result, noncompaction may be causally unrelated to cutaneous sclerosis, and this coexistence may be due to a second genetic problem.

\section{Belma Kalayc1, M.D., Süleyman Kalayc1, M.D.," Turgut Karabağ, M.D., Mustafa Aydın, M.D.}

Department of Cardiology, Bülent Ecevit University Faculty of Medicine, Zonguldak, Turkey

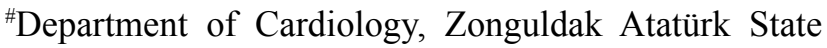
Hospital, Zonguldak, Turkey

e-mail: drbelma@hotmail.com

Conflict-of-interest issues regarding the authorship or article: None declared

\section{References}

1. Kalaycı B, Kalaycı S, Karabăg T, Aydın M. Biventricular noncompaction cardiomyopathy with severe systolic and diastolic dysfunction in a systemic sclerosis patient. Turk Kardiyol Dern Ars 2015;43:720-3. CrossRef

2. Stöllberger C, Feichtinger H, Heinrich I, Finsterer J. Cutaneous sclerosis associated with left ventricular noncompaction, myopathy, polyneuropathy and pancytopenia with eosinophilia. J Eur Acad Dermatol Venereol 2006;20:623-5. CrossRef

3. Dinser R, Frerix M, Meier FM, Klingel K, Rolf A. Endocardial and myocardial involvement in systemic sclerosis--is there a relevant inflammatory component? Joint Bone Spine 2013;80:320-3. CrossRef 